\title{
Watercress cultivation sites and their relationship to fascioliasis in Puerto Rico'
}

\author{
Pedro Bendezú ${ }^{2}$, Anne D. Frames, Edward L. Frame \\ and Carmelo Bonilla
}

\begin{abstract}
Watercress, Nasturtium officinale, is an edible semi-aquatic plant. It is considered to be the principal source of infection for human fascioliasis in Puerto Rico and elsewhere in the world. Commercially grown and natural watereress areas on the island were examined to determine the existing conditions which would contribute to the dissemination of Fasciola hepatica. The factors considered were: 1) the presence of the snail intermediate host (infected and uninfected) in the cress cultivation areas; 2) the presence of parasitized mammals in the area where contaminated fecal matter could be washed into the eress growing sites; 3 ) the presence of viable metacercariae encysted on watercress; and 4) human consumption of watercress from contaminated sites.

The nine commercial watercress cultivation sites examined were found free of infected sncils, free of watercress with viable metacercariae, and free of infected mammals in the area. On the other hand, of the 18 natural, unattended watereress growing sites, seven were found with infected snails, six of the sites had watercress with viable metacercaria, and nine of the sites had susceptible animals in the area.
\end{abstract}

\section{RESUMEN}

Siembras del berro y su relación con la fascioliasis en Puerto Rico

Nasturtium officinale, $\mathrm{R}$. Br. (Gray's Manual) es una planta semiacuática que se consume como ensalada en Puerto Rico. El consumo de berro es un medio de infección de la Fasciola hepafica al ingerir metacercarias enquistadas en la planta. Se estudiaron las zonas donde se cultiva el berro comercialmente y silvestre del norte para determinar qué factores contribuyen a diseminar la Fasciola hepafica.. Se consideraron los factores que siguen: 1) la presencia de caracoles hospederos intermediarios infectados o no infectados; 2) la presencia de animales susteptibles y parasitados; 3 ) la presencia de melacercarias enquistadas en la planta; y 4) el consumo de berro en la comunidad de las zonas contaminadas.

Los resultados de las muestras de caracoles lymnaea cubensis, berro y seis muestras de heces de los nueve viveros comerciales fueron negativos

${ }^{1}$ Manuseript submitted to Editorial Board 20 October 1986.

These investigations were supported by U. S. Public Health Service Grant No. RR 08159 administered through the Division of Research Resources, National Institutes of Health-Mimority Biomedical Research Support.

${ }^{2}$ Professor of Parasitology, Veterinarian, Inter American University of Puerto Rico.

${ }^{3}$ Professor of Parasitology-Microbiology Inter American University of Puerto Rico.

${ }^{4}$ Research participants of the MBRS Program. 
a formas larvarias y hueves de la Fasciola hepatica; siete de los 18 viveros naturales tenían caracoles infectados. De estos siete, seis fueron positivos a metacercaria. En dos viveros naturales de berro había animales susceptibles, to cual puede representar una fuente de infección.

\section{INTRODUCTION}

Watercress, Nasturtium officinale, is a semi-aquatic plant used as a leafy green salad or as garnish. It is known to have high mineral and vitamin content, but is seldom consumed in quantities large enough to be of substantial nutritional value. Ingestion of watercress with vegetation carrying the infective metacercariae can initiate fascioliasis. Watercress is considered to be the principal source of infection for human fascioliasis in Puerto Rico and other areas in the world $(1,2,3,6,7,8)$.

The high prevalenee of Fasciola hepatica (5) in dairy cattle in Puerto Rico enables this parasite to propagate. This disease is spread when animal fecal matter with parasite eggs is washed into fresh water bodies and eventually into watercress cultivation sites harboring snail hosts. In these environments the parasite miracidiae, capable of penetrating the appropriate snail host, are an important link in maintaining the cycle. Here the molluscan larval stages continue development until the cercariae are released, forming the infective metacercariae. Thus, watercress cultivation sites which harbor Lymnaea cubensis and Lymnaea columella, the intermediate hosts for Fasciola hepatica in Puerto Rico, represent a potential source of infection for the human population which consumes this vegetable.

\section{MATERIALS AND METHODS}

Commercial watercress beds in the towns of Caguas, Aguas Buenas, Río Grande and Corozal were examined for factors which would, if present, contribute to the dissemination of $F$. hepatica. The factors considered were the following: 1) the presence of parasitized animals whose fecal samples would be washed into the cress beds; 2 ) the presence of the snail intermediate hosts sharing the cress bed; 3) the presence of metacercariae encysted on the watercress; and 4) the use of watercress for human consumption.

From each cultivation site, samples of watercress and snails were collected from randomly selected sections of the site and examined in our laboratories. The immediate area of watereress growth site was observed for the presence of cows or goats that would be carriers of $F$. hepatica. Feeal samples were obtained rectally from available animals, and then taken to the laboratory for examination.

Nine commercial and 18 noncommercial watercress beds were visited. Information as to their location was obtained from the vendors and distributors of watercress. The commercial watercress cultivation sites were those which were owned and maintained by specific individuals who har- 
vest the plants for sale. The noncommercial watereress cultivation sites were those where cress grew naturally and sporadically, not maintained or owned by anybody. The watercress from these beds was gathered by vendors for sale or taken by passing individuals for personal use.

A survey on the consumption of watereress in a sample of 27 persons with fascioliasis was taken to determine the extent to which watercress was consumed and the source of the plant.

\section{RESULTS AND DISCUSSION}

The nine commercial watercress sites examined in 1982 were located as follows: three were in Corozal, two in Río Grande, and one in Gurabo, Aguas Buenas, Canóvanas, and Carolina (table 1). All nine commercial watereress beds were found to harbor one or more snail hosts for $F$. hepatica. L. cubensis was found in eight cress beds and Lymnaea columella was observed in five. In addition, eight cress beds also harbored $P h y s a$ species. In Puerto Rico, miracidiae of $F$. hepatica penetrate $P$ hysa species but do not complete development (De León et al., 1971). Biomphalaria glabrata, intermediate host for Schistosoma mansoni, was found in two of the cress beds: one in Corozal and the other in Gurabo.

The areas surrounding the commercial cultivation sites were examined for the presence of susceptible animals such as cattle, goats or sheep, but none were found in the vicinity at the time. These areas should be inspected periodically to avoid the entrance of infected animals which would deposit parasite eggs.

Snails were present in the commercial cress sites but none were infected with larvae of $F$. hepatica and no watercress could be found with the infective metacercariae attached. Nevertheless, the very presence of snail hosts in the cress beds represents a potential for the development of the cycle.

Natural watercress beds examined presented another picture (table 2). Seventeen of the 18 naturally growing unattended watercress beds were found harboring $L$. cubensis, and in seven of the beds snails infected with $F$, hepatica were found. $L$. columella was found in five of the 18 watereress beds but none were infected with larvae of $F$. hepatica. Metacercaria were found encysted on watercress taken from six of the 18 naturally growing cress beds. Infected cattle were found in the area of 10 of the natural sites.

In barrio Magüeyes of Corozal, Cerro Gordo of San Lorenzo and Río Cañas of Caguas, only a few cows $(3,2$, and 3 , respectively) were found in the area and were negative for $F$. hepatica. The watereress of these beds had metacercariae cysts and the snails found were free of $F$. hepatica.

In the sector of Cibuco and Palmarejo of Corozal, Jaguar of Gurabo, Barrazas of Carolina, and Higuillar of Dorado, infected cows, infected 
TABLE 1.-Commercial watereress cultivation sites

\begin{tabular}{|c|c|c|c|c|c|c|c|c|}
\hline \multirow{3}{*}{ Town } & \multirow{3}{*}{ Community } & \multicolumn{4}{|c|}{ Snail hosts } & \multirow{3}{*}{ Watercress } & \multirow{3}{*}{$\begin{array}{c}\begin{array}{c}\text { Susceptible } \\
\text { animals }\end{array} \\
\text { e present }\end{array}$} & \multirow{3}{*}{$\begin{array}{c}\text { Fecal } \\
\text { examination }\end{array}$} \\
\hline & & \multicolumn{2}{|c|}{ Fosstria cubensis } & \multicolumn{2}{|c|}{ Lymnata colnomella } & & & \\
\hline & & $\mathrm{P}^{1}$ & $1^{2}$ & $\mathrm{P}_{1}$ & $I^{2}$ & & & \\
\hline \multirow{3}{*}{ Corozal } & Mana & + & $0^{3}$ & 0 & 0 & 0 & 0 & 0 \\
\hline & Cuchilla & + & 0 & + & 0 & 0 & 0 & 0 \\
\hline & Negro & + & 0 & 0 & 0 & 0 & 0 & 0 \\
\hline Gurabo & Masa & + & 0 & 0 & 0 & 0 & 0 & 0 \\
\hline Aguas Buenas & Bayamoncito & + & 0 & + & 0 & 0 & 0 & 0 \\
\hline \multirow[t]{2}{*}{ Canóvanas } & Cubuy & 0 & 0 & + & 0 & 0 & 0 & 0 \\
\hline & Guzmán Arriba & + & 0 & + & 0 & 0 & 0 & 0 \\
\hline Río Grande & Guzmán Abajo & + & 0 & + & 0 & 0 & 0 & 0 \\
\hline Carolina & Sabana Abajo & + & 0 & 0 & 0 & 0 & 0 & 0 \\
\hline Total & & 8 & 0 & 5 & 0 & 0 & 0 & 0 \\
\hline \multicolumn{9}{|c|}{$\begin{array}{l}\text { Present. } \\
\text { 'Infection. } \\
{ }^{2}+=\text { Positive; } 0=\text { Negative. }\end{array}$} \\
\hline
\end{tabular}


TABIE 2.-Some natural watercress cultivation sites in Puerto Rico

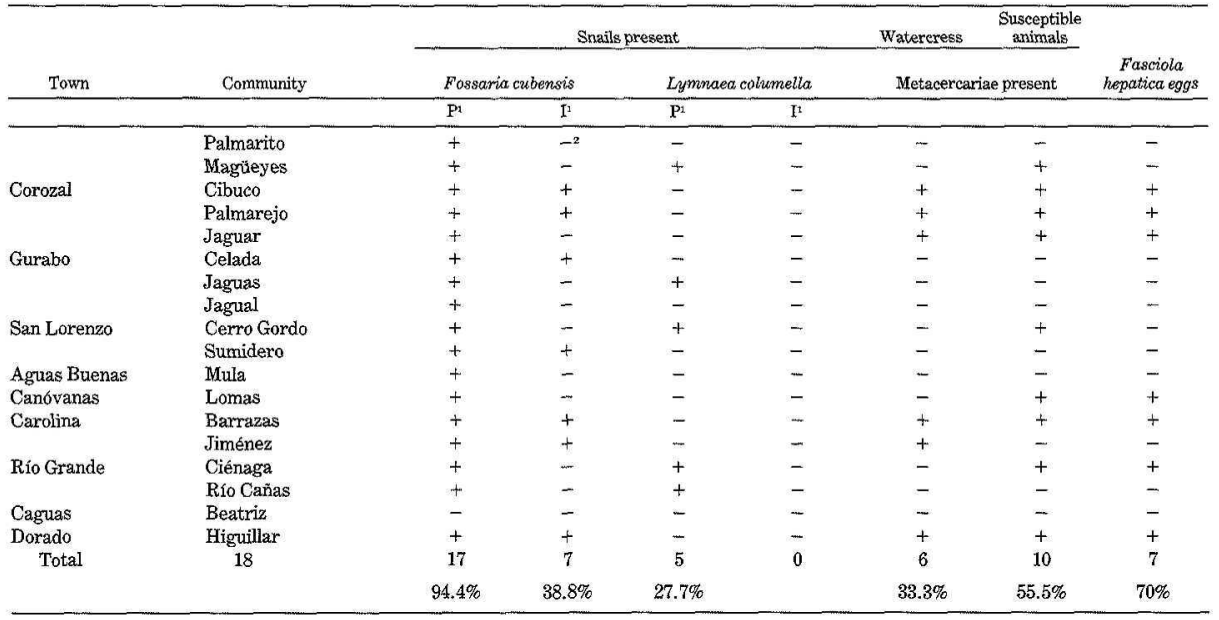

IP $=$ Present; $\mathrm{I}=$ Infection.

$2+=$ Positive; - = Negative. 
snails and watercress with metacercariae were all found in the area of the cress cultivation sites. In Canovvanas and Ciénaga of Río Grande, positive cows were found in the area, but the snails and watercress were negative.

In Barrio Jiménez of Río Grande, infected snails and watercress with metacercariae were found but no susceptible domestic animals were seen in the area at the time. Perhaps infected cows, goats and other infected mammals may have passed through the area depositing parasite eggs with fecal matter.

After a rainfall, soil washing drains down to the streams and rivers where watercress grows. If the parasite eggs washed into the cress beds hatch and the miracidiae meet the snail intermediate hosts, then that phase of the parasite cycle begins with the formation of the molluscan larval stages.

According to our survey of 27 persons positive for $F$. hepatica, 23 $(85 \%)$ admitted to consuming watercress regularly, when it was available. Four of these persons drank water from the river on occasion because it was "fresh". The infected persons interviewed said they generally purchased watercress at the market place and from ambulatory vendors. The snail and ambulatory vendors who generally sell along the roadside or in neighborhoods obtained watercress from the natural unattended cress sites because it was obtained at a lower price or at no cost at all if they gathered the watereress themselves.

In summary, the nine commercial watercress cultivation sites examined were found free of infective snails, free of watercress with the infective metacercariae, and free of infected mammals in the area. On the other hand, of the 18 natural unattended watercress growing sites, seven $(38 \%)$ of the sites were found with infected snails, six $(33.3 \%)$ had watercress with metacercariae and ten $(55.5 \%)$ of the sites had susceptible animals in the area. These naturally growing watercress sites represent a potential source of fascioliasis on the island.

\section{LITERATURE CITED}

1. Ashton, W. L. G., P. L. Boardman, P. H. Everall and A. W. J. Houghton, 1972. Human fascioliasis in Shropshire. Br. Med. J., 3: 500-02.

2. Bendezú, P., A. D. Frame and G. V. Hillyer, 1982. Human fascioliasis in Corozal, Puerto Rico. J. Parasitol. 68 (2): 297-99.

3. Bryan, F. L., 1977. Diseases transmitted by foods contaminated by waste water. $J$. Food Prot. 40 (1): $45-46$.

4. De León, D. D., L. Ritchie and J. Chiriboga, 1971. Refractivenerss of Physa cubensis (Pfeiffer) and Aplewa mormorata (Guilding) to Fasciola hepatica (L.). I. Agric. Univ. P. R. 55 (2): 267-70.

5. Frame, A. and P. Bendezú, 1978. Bovine fascioliasis in Puerto Rico. J. Parusitol., 64: 136.

6. Hardman, E. W., R. L. H. Jones and A. H. Davies, 1970. Faseiolizsis-A large outbreak. Br. Med. J. 3: 502-05. 
J. Agric. Univ. P.R. VoL. 72, NO. 3, JULY, 1988

7. Hillyer, G. V., 1981. Faseioliasis in Puerto Rico: A Review. Vol. Asoc. Med. P. R, 73 (3): 94-101.

8. Rondelaud, D., 1978. The watercress pools in connection with cases of human fascioliasis in Limousin, France. Experimental studies of snail vectors and their biological control. Annu. Farasitol. Hum. Comp. $53(6): 623-30$. 
